FROM COMPASS TO COMPUTER

A History of Electrical and Electronics Engineering 


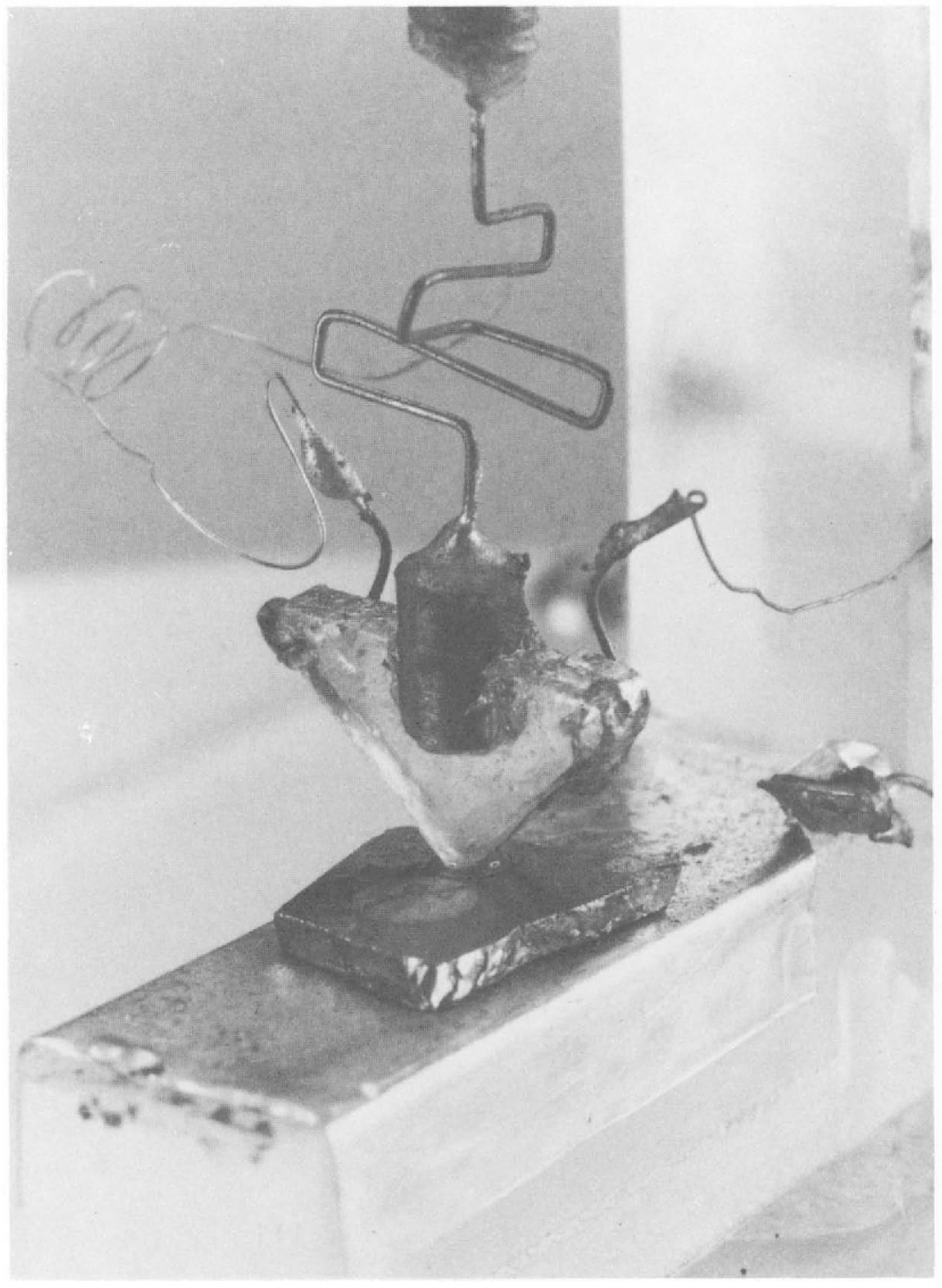

The start of the transistor era; the first point-contact transistor made on 23 December 1947 (Courtesy of Bell Laboratories) 


\title{
From Compass to Computer
}

\section{A History of Electrical and Electronics Engineering}

\author{
W. A. Atherton
}

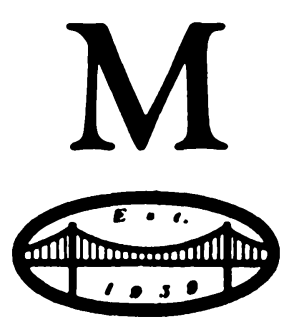

San Prancisca Opress, Pre. Box 6800, San Francisco, CA 94101-6800, USA 
(C) W. A. Atherton 1984

Softcover reprint of the hardcover 1st edition 1984

All rights reserved. No part of this publication may be reproduced or transmitted, in any form or by any means, without permission.

First published 1984 by

THE MACMILLAN PRESS LTD

London and Basingstoke

Companies and representatives

throughout the world

and in the United States of America and Canada by

San Francisco Press, Inc.

Box 6800, San Francisco, CA 94101-6800, USA

Printed in Hong Kong

ISBN 978-0-333-35268-7

ISBN 978-1-349-17365-5 (eBook)

DOI 10.1007/978-1-349-17365-5

Library of Congress Card Catalogue Number 83-61209 


\section{CONTENTS}

Foreword viii

Preface $\quad$ xi

Acknowledgments xiii

1 Introduction 1

2 Electricity and Magnetism to $1820 \quad 13$

$\begin{array}{ll}\text { Experimental Discoveries } & 15\end{array}$

$\begin{array}{ll}\text { Evolution of Theory } & 18\end{array}$

$\begin{array}{ll}\text { Electric Current } & 21\end{array}$

3 The 1820s: Dawn of a New Age 30

Oersted's Discovery 31

Ampère and Others $\quad 33$

The Electromagnet $\quad 38$

Laws of Conduction $\quad 42$

4 Electromagnetism $\quad 49$

Michael Faraday $\quad 52$

Electromagnetic Theory $\quad 61$

Acceptance of Maxwell's Theory $\quad 68$

$\begin{array}{ll}\text { Relativity and Quanta } & 74\end{array}$

$\begin{array}{ll}\text { Conclusion } & 77\end{array}$

5 Telecommunications $\quad \mathbf{8 0}$

$\begin{array}{lr}\text { European Electromagnetic Telegraphs } & 83\end{array}$

$\begin{array}{ll}\text { Telegraphy in America } & 88\end{array}$

Social Impact $\quad 91$

Submarine Telegraphy $\quad 92$ 
Technical Improvements $\quad 96$

$\begin{array}{lr}\text { The Telephone } & 100\end{array}$

$\begin{array}{ll}\text { Advancement of Theory } & 108\end{array}$

The Modern Era 111

6 Electric Lighting and Its Consequences 116

$\begin{array}{ll}\text { The Rivals } & 117\end{array}$

Arc Lamps Make a False Start $\quad 117$

Generators: Pixii to Gramme 119

$\begin{array}{ll}\text { Commercial Arc Lighting } & 123\end{array}$

$\begin{array}{ll}\text { The Incandescent Lamp } & 127\end{array}$

$\begin{array}{lr}\text { Edison } & 129\end{array}$

Swan 131

Other Inventors $\quad 133$

Commercial Development $\quad 133$

Metal Filament Lamps 137

Discharge, Fluorescent, and Other Lamps $\quad 140$

$\begin{array}{ll}\text { Impact of Electric Lighting } & 144\end{array}$

7 Electrical Power $\quad 147$

DC Dynamo Design 149

DC Motors $\quad 152$

AC Generators and Motors $\quad 154$

$\begin{array}{ll}\text { Traction } & 165\end{array}$

Industrial Use $\quad 174$

$\begin{array}{ll}\text { Domestic Use } & 178\end{array}$

$\begin{array}{ll}\text { Conclusion } & 180\end{array}$

8 Radio $\quad 182$

$\begin{array}{ll}\text { Prehistory } & 182\end{array}$

$\begin{array}{ll}\text { Radiotelegraphy } & 184\end{array}$

$\begin{array}{ll}\text { Marconi } & 186\end{array}$

Other Inventors $\quad 190$

Arcs and Alternators $\quad 191$

Electronic Radio $\quad 194$

FM Radio $\quad 204$

Television $\quad 205$

Radar $\quad 212$

9 Some Theories and Discoveries 216

$\begin{array}{ll}\text { The Electron } & 216\end{array}$

Magnetism $\quad 222$

Towards Information Theory $\quad 225$

$\begin{array}{ll}\text { Noise } & 233\end{array}$

Electrical Units $\quad 234$ 
10 Miniaturization of Electronics $\quad 237$

Improvement of Understanding and of Materials 239

$\begin{array}{ll}\text { The Transistor } & 242\end{array}$

$\begin{array}{ll}\text { Miniaturization } & 250\end{array}$

Field-effect Transistors (FETs) 260

Impact of Integrated Circuits 263

11 Computers $\quad 268$

The Development Period $\quad 272$

$\begin{array}{ll}\text { Germany } & 276\end{array}$

$\begin{array}{ll}\text { United States } & 277\end{array}$

$\begin{array}{ll}\text { Britain } & 283\end{array}$

The Computer Industry $\quad 286$

$\begin{array}{ll}\text { First Generation } & 287\end{array}$

Second and Later Generations $\quad 290$

Minis and Micros $\quad 295$

Digital Logic Circuitry $\quad 301$

Programming Languages $\quad 303$

$\begin{array}{ll}\text { FORTRAN } & 305\end{array}$

ALGOL $\quad 305$

$\begin{array}{ll}\text { COBOL } & 306\end{array}$

PL/1 and Others $\quad 306$

$\begin{array}{ll}\text { Conclusion } & 307\end{array}$

12 A Technological Society 310

$\begin{array}{ll}\text { Name Index } & 324\end{array}$

$\begin{array}{ll}\text { Subject Index } & 330\end{array}$ 


\section{FOREWORD}

Our awareness of electricity, of all the forces of nature, developed entirely from man's innate curiosity about how certain materials behaved. From a slow beginning, electrical knowledge was a product of the 1800 s, as nuclear energy is a product of the 1900 s. Why did amber attract feathers and other light bodies? The answer, first attempted by Gilbert in 1600, is still in the process of formulation. Electrical science and engineering, one of the youngest disciplines, has become as extensive as it has grown universal, and all its flowering is crowded into only one century.

The Renaissance was followed by the Enlightenment, the Industrial Revolution, the Age of Power, the Electrical Age, and now the Age of Electronics. Each age has had a survival period of successively shorter duration, which reflects the erupting increases in channels of communication and knowledge retrieval. Our lives have about doubled in length in a century and our numbers have quadrupled. The survival factor, the sense of security, has kept pace, in spite of the present build-up of nuclear armaments and threats of violence in some locations. The slow but constant penetration of electronic intelligence does not make headlines, but its effect has been long lasting.

Fathered by scientific thought and mothered by experimental research, electrical progress is fittingly illustrated by the invention of the transistor. The last two centuries have provided mankind with a heritage of technological advances of greater beneficence that all the theocratic or political promises of the past ages. Through it all are woven the contributions of the electrical and electronics engineers with generators and controls so powerful and so delicate as to affect every product and process in which man is engaged.

Two dates - both easy to remember - mark the advent of the electrical age. In 1600 William Gilbert, physician to Queen Elizabeth I of England, published a treatise on the magnet in which electrical attraction is described. In 1800 Alessandro Volta, professor of physics at Pavia, published, in London, his invention of the electric battery, a source of continuous (direct) current. The magnetic component of this current became the source of today's 
electrical generation and the trigger to the great power supply that moves our world. Invisible and subtle, unknown two centuries ago, electric power has become the basic influence in the life of mankind.

The application of electromagnetic waves followed Hertz's demonstration of their reflection, refraction, and radiation. That occurred only a century ago, in the year when the term electron was first used. From it flowered a variety of communication systems that have permanently changed our habits and traditional institutions. The drama of reporting a Titanic disaster, an air raid on a metropolis, or an assassination attempt on a pope or a president brings home to a citizen a flavour unmatched by literature or oratory. Reporting from the moon or probing into outer space via electronics provides a credibility value exceeding the talents of a Jules Verne or Henry Stanley. We now view the universe's vastness and complexity undreamed of by Giordano Bruno or Edwin Hubble. We are still receiving reports from probes shot into space seven years ago from spacecraft travelling at speeds of over 25000 miles per hour, which had long ago passed through the orbits of Jupiter and Saturn.

What has been accomplished by radio, radar, television, satellite telephony, and lasers in penetrating space and disseminating events in the macrocosm has been matched by the marvels of penetration into the structure of matter in the microcosmic domain. There emerge the scores of particle and energy components revealed by the electron microscope, $x$ rays, and the particle accelerator. What Einstein, Bohr, and Fermi started has grown into an arcane and complex body of knowledge and conjecture for which billions are now budgeted by nations and universities so as to extend the frontiers of electromagnetic understanding. We have watched the development of the silicon chip with resulting computer and data bank so compact and comprehensive that nations compete in providing the maximum data in least space. Recent designs of computers and integrated circuits so shrank the electronic components that what can now be held in the palm of a hand functions better than earlier types that filled a space of a hundred cubic meters. This miniaturization in turn opened up dozens of new avenues of application, such as radar surveying, proximity fuzing in ballistic weaponry, radar exploration, and radioastronomy. What the thermionic valve (vacuum tube) had done for electronic radio, the silicon chip now does for integrated circuitry and data storage. The speed at which new inventions are absorbed into our industrialized economy is indicated by the growth of integrated circuitry in the USA, which rose from their introduction in 1964 to a value of over $\$ 5$ billion in a dozen years.

Like the abacus and the mechanical calculator, the electronic computer has joined the myriad other devices for doing things more quickly, better, and more cheaply. Computer design and fabrication have become the world's third largest industry. The first industrial revolution improved physical tools, the second revolution evolved better mental tools; data processing and ready computing facility characterize the present fast-moving period of time. Data banks are to be made available for all who seek information in our coming 
society. Electrical science and engineering are now making their bid to satisfy man's hunger to learn. Memory capacities double and triple with each new model series. A wafer can now hold several hundred chips, and each chip contains some 250000 transistors and similar elements. Each transistor is about 0.003 inch across. A television assembly is now crowded into a wristwatch space. We are truly crossing a threshold. 


\section{PREFACE}

Most electrical and electronics engineers and technicians know very little about the history of their chosen profession. During their education and training they are offered minimal information on this subject-what they do learn often comes in the form of anecdotal footnotes in textbooks or as the reminiscences of an older generation. This book is offered to engineers, technicians, and students, not so much as a textbook but more as an account that may be read for enjoyment and relaxation as well as for enlightenment.

In common with the history of other branches of engineering, and with those of physics and science in general, the history of electrical and electronics engineering has become a profession in itself. Indeed much of the material on the subject seems to be written by historians for historians, which is a pity. I am not an historian and make no claim to be one. This book is not written for historians; they have their own sources, methods, and standards to which those of the engineering fraternity do not often refer. My aim has merely been to bring to a wider audience that which is already known to a select few. The result contains little original material but, I hope, much that engineers and interested laymen will find interesting and informative.

There is a growing awareness of the history of their discipline among electrical engineers. In America the Institute of Electrical and Electronics Engineers, Inc., welcomes papers on historical topics in its Transactions and has established a History Center in New York. In Britain the Institution of Electrical Engineers hold an annual meeting on history. Some Colleges and Universities offer short courses in the history of electrical engineering to engineering students. If this book serves to foster that awareness in some small way it will have been worthwhile.

Colyton, Devon, 1983

W. A. ATHERTON 


\section{ACKNOWLEDGMENTS}

Many people and organizations have encouraged this work by providing help, information and advice; though too numerous to mention individually, to all I express my thanks. Especially I thank the University of Hong Kong, where much of this work was done, and the staff of the History and Electrical Engineering Departments; also Professor Charles Süsskind of the University of California, Berkeley, who edited the manuscript and made many useful suggestions.

\section{Figure credits}

Illustrations and photographs courtesy of, or by permission of:

Bell Laboratories: Frontispiece, Figures 1.1, 1.2, 5.9, 5.10, 9.1, 10.2(a). Cork B. V., Netherlands: Cartoon chapter 9.

A. J. Croft, Clarendon Laboratory, University of Oxford: Figure 2.5. Digital Press/Digital Equipment Corporation: Figures 11.8, 11.9, 11.10. Edison National Historic Site, West Orange, N. J.: Figure 8.4.

Ferranti Company: Figure 7.5.

General Electric: Figures 6.2, 6.4, 6.5, 6.6, 6.7, 6.8(b), cartoon chapter 6. Harvard University Press: Figures 2.4, 4.6 (redrawn).

Hewlett-Packard Company: Figure 12.1.

Illustrated London News: Figure 5.6 (redrawn).

Institution of Electrical Engineers: Figures 1.5, 2.1, 2.2, 2.3.

Intel Corporation: Figures 11.11, 11.12.

International Business Machines Corporation: Figures 11.1, 11.3, 11.7.

International Computers Ltd.: Figure 11.6.

Marconi Company Ltd.: Figures 1.3, 8.1, 8.5(c).

McGraw-Hill Inc., Electronics, Copyright (C) 1948: Figure 10.3.

Oxford University Press: Figure 7.2(a).

Pergamon Press, London (G. W. A. Dummer, Electronic Inventions, 17451946, 1977): Figure 10.9(a).

Punch: Figures 7.1, 8.8, 8.9. 
Public Record Office, Crown Copyright: Figures 1.4, 11.5.

RCA Corporation: Figure 8.10(b).

RCA Laboratories: Figures 10.5, 8.12.

Royal Institution, London: Figure 4.2.

Science Museum, London, Crown Copyright: Figures 7.2(b), 8.6(a).

Photo. Science Museum, London: Figures 8.10(a), 10.1.

Siemens Museum, Munich: Figures 5.5, 7.3, 7.7.

Smithsonian Institution, Washington, D. C.: Figure 5.7.

J. J. Suran, GE, USA: Figure 10.8 .

Texas Instruments Inc.: Figure 10.6.

Thorn EMI Lighting: Figure 6.8(a). 